\title{
Research on the Construction of Support System of University Students' Entrepreneurship Education under the Background of the New Normal
}

\author{
Yiyi Xu \\ Zhejiang Tongji Vocational College of Science and Technology, Hangzhou, 310000, China
}

Keywords: Support system, Entrepreneurship education, New normal.

\begin{abstract}
Strengthening the entrepreneurship education of university students is a new requirement for higher education under the new normal conditions of economic and social development. However, the entrepreneurship education in universities needs good construction of a support system, including the curriculum setting, training base and teacher resources. Under the background of the new normal, China's university entrepreneurship education support system is still not perfect. This paper analyses the paths to improve the supporting system of entrepreneurship education to provide some references for the relative researchers.
\end{abstract}

\section{Introduction}

Along with the profound changes in national conditions, China's social and economic development is entering the new normal. As a valuable national talent resource, college students are the fresh force of innovation and entrepreneurship. Therefore, it has become an important part of college students' work to actively promote the innovation and entrepreneurship education in colleges and universities, and to guide and motivate college students to join the practice of innovation and entrepreneurship. China's higher education has entered the stage of popular education from elite education, expand the scale of higher education, Chinese economic development of the new normal, which makes college students face severe employment pressure, if only pay more attention to the cultivation of knowledge talent has been unable to meet the development and enhance the competitiveness of students in colleges and universities differentiated demand. The construction of entrepreneurship education support system perfect, change the mode of thinking of entrepreneurship education in universities. Under the new normal economy, college students are faced with difficulties in employment. Entrepreneurship education support system is a systematic project. It is an organic whole composed of entrepreneurial environment system, entrepreneurship service system, entrepreneurship education system and entrepreneurial platform system. Under the actual conditions, the plight of college students' innovation and entrepreneurship education not only affects the quality of personnel training in universities, but also becomes a bottleneck restricting the reform of higher education in china. Therefore, the sober understanding of the new normal background of the plight of college students' innovation and entrepreneurship education is an important prerequisite for exploring the path of great change. At present, the development of innovation and entrepreneurship education support system in China's universities is still in the stage of exploration and development, and there are still many problems that cannot be ignored.

\section{Inadequacies of Support System of Entrepreneurship Education under the Background of the New Normal}

Unreasonable Curriculum System. Entrepreneurship education is still in an marginalized position in some colleges and universities, and has not really integrated into the curriculum system and personnel training of various majors. In the scheme, there is no clear goal of education teaching 
task, teaching syllabus is not complete, the teaching form is the elective course, lectures, distance education, teaching content and professional education and is not tight, still adopt the traditional teaching mode to instill knowledge, combined with the lack of innovation theory and innovation practice. At present, the curriculum system of entrepreneurship education for college students is not perfect. Many colleges and universities lack independent, scientific and reasonable curriculum system, especially in the systematization and practice of entrepreneurship education. In the course content, more theoretical based, the lack of specific practical guidance. In addition to the basis of entrepreneurship, most of them belong to the career planning and career guidance series. They ignore the subjectivity of college students in the setting of the curriculum system, and ignore the requirements of social development and economic characteristics. On the one hand, entrepreneurship education has not run through college education, and there is no effective logical connection between it and other courses. On the other hand, all students of entrepreneurship education are the same, there is no specific professional, pay no attention to the inquiry learning of college students, lead to the goal of entrepreneurship education is not clear, the direction is not clear, the teaching method is not correct a series of questions. In some universities, entrepreneurship courses are taken as elective courses, which are offered to some students. In some universities, there is no entrepreneurship course in the teaching plan. The low rate of entrepreneurship courses and the narrow scope of teaching restrict the development of College Students' entrepreneurship education, and it is not conducive to improving their innovative awareness and entrepreneurial ability.

Deficient Training Bases. At present, colleges and universities basically carry out employment education, and only take entrepreneurship education as part of the employment education. They simply teach the basic theory knowledge and national policy guidance to college students. Have the ability to set up a separate business school education curriculum innovation, but also to the traditional classroom teaching is the main mode of entrepreneurial activities, lack of guidance and support, to mobilize the enthusiasm and initiative of students, poor educational outcomes. In addition, it is difficult to build a practical platform for innovation and entrepreneurship education. Therefore, how to let college students close contact with the entrepreneurial process, and personally experience the effective occurrence of entrepreneurial activities, has become a great challenge for college students' innovation and entrepreneurship education. Most schools generally use the practice teaching methods, mostly in the school laboratory, through the specialized software simulation actual operation. But the real business environment is much more complex than the simulation environment, and the simulation software cannot be upgraded in time, so the students' practical ability is restricted. Social misspace product innovation as the core goal, its mode of operation can be flexible, diverse, and creating education emphasizes the students' innovation ability and cultivating customer quality, should be emphasis on creating activities and teaching combination. The entrepreneurial services in the training base are not only geared to the entrepreneurial teams, but also to the individuals, teams and small and micro enterprises outside the base. Through the introduction of neighboring excellent enterprise resources, universities and enterprises build a creative space to encourage and guide students to join the creative team actively.

Weak Teacher Resources. Innovation and entrepreneurship education requires teachers have a double condition of theory and practice, the general lack of this kind of innovation and Entrepreneurship of college teachers from many teachers of economic management professional teachers or counselors, have more understanding of theoretical knowledge, but have not received professional training and lack of work experience, cannot be better to combine theory and practice up. At present, teachers have become the short board of innovation and entrepreneurship education in universities. The mode of continuing college students' career guidance and education, and the teaching staff of innovation and entrepreneurship education, mainly depend on the management of students. On the one hand, most of the teachers only after a brief training began to bear responsibility for innovation and entrepreneurship education, not only the lack of professional knowledge, lack of entrepreneurial experience, are not familiar with the operation of enterprises, more familiar with the market demand, not on innovation and entrepreneurship education, to give students targeted guidance. On the other hand, the teachers who take the courses of innovation and entrepreneurship education 
are mostly part-time, not only to complete their own work, but also to complete the subsidiary work of innovation and entrepreneurship education. Their teaching experience is not enough, and their enthusiasm is not high. At present, the teaching of entrepreneurship education courses in Colleges and universities are mostly accompanied by other related professional teachers. They have neither the basic knowledge of entrepreneurship and the lack of practical experience in entrepreneurship. These teachers are to explain the entrepreneurship courses from their own professional point of view. At the same time, due to the lack of entrepreneurial experience, entrepreneurship courses teaching teachers in the teaching process pays more attention on theoretical knowledge, neglect or difficult to carry out practice teaching, so that the entrepreneurship education appeared a serious gap between theory and practice, students' entrepreneurial ability problems.

\section{Construction Paths of Support System of Entrepreneurship Education under the Background of the New Normal}

Improve the Construction of Curriculum System. Curriculum is the basic carrier of innovation and entrepreneurship education in Colleges and universities, and strengthening the construction of innovation and entrepreneurship courses is an important step in the implementation of innovative entrepreneurship education. Colleges and universities can establish modular curriculum system according to their own characteristics, and use the network resources and various channels to study and introduce excellent innovative entrepreneurship education courses in other universities at home and abroad. According to the students' grade and specialty, combined with the employment ability demand, we will set up targeted entrepreneurial courses, and develop modularized, functional and modular courses. We should consider how to focus on the concept of innovation and entrepreneurship will be effectively integrated into the teaching system. The cultivation of innovative business philosophy has become one of the leading professional teaching. We will further optimize and perfect the measures for the assessment and management of innovative credits for college students, and encourage them to manage the innovation and entrepreneurship projects and the achievements and benefits of the students. We integrate the idea of innovation and entrepreneurship into the management of teaching, integrate the curriculum resources with the idea of innovation and entrepreneurship, and establish an interdisciplinary and comprehensive integrated course of entrepreneurship based on the relevance of entrepreneurial knowledge. In the process of curriculum in colleges should know the curriculum theory, entrepreneurial skills and entrepreneurial enterprise management business, but also opened the international economic and trade cultural public course, but also to the latest scientific and technological achievements into the course. The course of entrepreneurship education should be set up for discussion, research and practice, and actively explore to practice teaching, scientific research, innovation, design, etc. as an extension of classroom teaching.

Strengthen the Construction of Training Bases. Actively promote the cooperation between schools and enterprises and establish a practice base for innovation and entrepreneurship. Colleges and universities should innovate cooperation through the work of thinking, build a training base, business school, co-founded the company, to build a solid research center, the construction of school enterprise integration, open cooperation to build a diversified pattern. Universities and enterprises jointly carry out the training of professional managers' qualification certification, jointly study and formulate certificate training system, and introduce vocational certificate training into the education of innovation and entrepreneurship. Colleges and universities should establish fund innovation and entrepreneurship students, improve students innovative project declaration system, support and help the students to use the school laboratory, subject teachers or enterprises, to new technologies and methods, the major domestic and foreign enterprises such as the topic to carry out innovative practice problems. According to their own specialty and research interests, students may enroll in the corresponding research centers and laboratories, and carry out research projects and technological innovation under the guidance of tutors. At the same time, we will actively create conditions for the development and transfer of scientific and technological achievements with promising prospects, and 
commend the excellent individuals in scientific and technological innovation activities. Entrepreneurial training base is a platform for college students to start their business practice, which helps to improve their entrepreneurial ability and accumulate entrepreneurial experience. Schools can combine their own practice to establish entrepreneurial training bases. On the one hand, schools can make use of some spare buildings for simple decoration, and then provide students with Entrepreneurship tests. On the other hand, schools can cooperate with enterprises to establish a training base for college students. It is an effective way for enterprises to fulfill their social responsibilities to provide entrepreneurial training positions for enterprises. It is beneficial to enhance the social awareness of enterprises and enhance their core competitiveness.

Modify the Construction of Teacher Resources. Constantly expand the Faculty of entrepreneurship education in colleges and universities, and optimize the teachers' strength in entrepreneurship education. The lack of teachers will restrict the development of entrepreneurship education. Therefore, it is very important to set up and train a group of professional teaching staff. We can choose the right people in the University's economic management and employment guidance teachers, and also employ some employees from various trades as the teachers of entrepreneurship education. We train teachers to learn about entrepreneurship education and teaching knowledge. Some business education seminars will be held regularly to enable teachers to exchange experiences with each other, and to improve the teaching and education level of teachers in order to meet the needs of the development of entrepreneurship education. With innovative consciousness and ability of the staff in the existing employment guidance teachers, through education, training, such as business consultants, business refers to the qualification training and certification of tutors, entrepreneurship training division, the rapid increase in the level of innovation and Entrepreneurship theory, formed the basis of the team innovation and entrepreneurship education, for all students to carry out innovation and entrepreneurship education. We encourage teachers to enterprise practice, or build a business platform for practice to provide personalized, targeted business practice guidance. We should fully tap the resources outside the school, invited experts, entrepreneurs, entrepreneurship education business executives, venture capitalists and other parties into the campus, jointly set up a business mentor team in colleges and universities to organize entrepreneurship lectures and case discussion.

\section{Conclusion}

As China's economic development has entered a new normal state, it has become an important aspect of the reform of higher education to promote entrepreneurship education. Further strengthening the construction of curriculum system, training base and teacher resources in entrepreneurship education in colleges and universities is conducive to strengthening the support system of the entrepreneurship education, which lays a good foundation for the development of the entrepreneurship education in colleges and universities.

\section{References}

[1] Wu Hao. The Status quo and Countermeasures of University Students Innovation and Entrepreneurship Education Under the New Normal Condition [J]. Journal of North University of China (Social Science Edition), 2016, 32(5): 60-63.

[2] Zhang Shiwei. Difficulties, Causes and Solutions of Entrepreneurship Education of Local Universities in the New Normal [J]. Theory and Practice of Education, 2015,35(33): 6-8.

[3] Zhao Xuexun, Tan Ying, Wang Fengchang, Xiao Zhao. On the Entrepreneurship Education of University Students from the Perspective of the New Normal State- Taking Jianghan University as an Example [J]. Journal of Jianghan University (Social Science Edition), 2015, 32(5): 114-119+129.

[4] Wang Jiahui. College students innovative and entrepreneurial education under new normal back ground [J]. Experimental Technology and Management, 2016, 33(8): 217-219+224. 